\title{
IMPLEMENTASI PEMBELAJARAN IPS BERBASIS KURIKULUM 2013 MELALUI LESSON STUDY DI SEKOLAH MUHAMMADIYAH KARTASURA
}

\author{
Tjipto Subadi ${ }^{1}$ Kuswaji Dwi Priyono $^{2}$. Dahroni ${ }^{1}$. M. Musyiyam ${ }^{1}$ \\ ${ }^{1}$ Pendidikan Geografi - Fakultas Keguruan dan Ilmu Pendidikan \\ ${ }^{2}$ Fakultas Geografi \\ Universitas Muhammadiyah Surakarta \\ *) e-mail: tjipto.subadi@ums.ac.id
}

\begin{abstract}
The purpose of this community service, assess and understand; 1) learning implementation strategy IPS (Social Sciences) Curriculum 2013 based on lesson study in the School of Muhammadiyah Kartasura. 2) Rationalization and elements of curriculum change in 2013. 3) The process of learning and assessment processes appropriate to the curriculum in 2013. The method used; workshops and training. The Place; SMK Muhammadiyah Kartasura. Execution time; odd semester 2014/ 2015. Subject: Elementary School teachers, Junior High School, High School and Vocational High School Muhammadiyah Kartasura. The results achieved; 1) learning implementation strategy IPS (Social Sciences) curriculum-based lesson study 203 through three stages, namely; plan (planning), do (action and observation), see (reflection). 2) Rationalization and elements of curriculum change in 2013 stressed on; a) The scientific approach is based approach to encourage student creativity; $b$ ) Integrity of the competence of knowledge, skills, and attitudes; c) Integrity of the curricular, co-curricular and extra-curricular activities. 3) The learning process is emphasized in the curriculum in 2013; (A) Integrated Thematic for elementary school level, (b) Approach Science (Natural Sciences) and IPS (Social Sciences) of partitive aggregative be integrated melt (liquid integrative), (c) religious and moral education, (d) learning objects; natural phenomena, social, and cultural arts. While the emphasis in the assessment process; assessment student achievement by using descriptive qualitative and quantitative numerical. Learning implementation strategy IPS (Social Sciences) 203 curriculum-based lesson study using a modified model of lesson study, achievement indicators for a significant increase from the prior worhshop and training after the workshop, namely; 30\%: 80\% (pre-test: post-test).
\end{abstract}

Kata Kunci: implementasi, pembelajaran, IPS, rasionalisasi, kurikulum, saintifik, lesson study

\section{PENDAHULUAN}

Bergantinya kurikulum dari kurikulum sebelumnya menjadi kurikulum 2013, yaitu; Kurikulum 1968, Kurikulum
1975, kurikulum1984, Kurikulum 1994, Kurikulum 2004 atau Kurikulum Berbasis Kompetensi, Kurikulum Tingkat Satuan Pendidikan (KTSP), dan yang terakhir ini 
Kurikulum 2013 sebagai salah satu bentuk dinamisasi dan inovasi pendidikan di Indonesia, yang harus disikapi sedini mungkin oleh pendidik (guru) agar para guru tidak mengahadapi kesulitan ketika harus melaksanakan diberlakukannya kurikulum baru (2013) di semuan kelas pada semua jenjang pendidikan.

Perubahan kurikulum itu dimaksudkan untuk memperbaiki sitem pendidikan dan rendahnya mutu pendidikan yang saat ini pada posisi sangat meprihatinkan jika dibandingkan dengan mutu pendidikan di negara-negara tetangga. Data rendahnya mutu pendidikan ditunjukkan oleh UNESCO (2000) bahwa catatan peringkat Indeks Pengembangan Manusia(Human Development Index) dari 174 negara di dunia, Indonesia menempati urutan ke-120 (1996), ke-105 (1998), dan ke-109 (1999). Survey Political and Economic Risk Consultant juga mencatat bahwa; kualitas pendidikan di Indonesia berada pada urutan ke-12 dari 12 negara di Asia, data itu menempatkan posisi Indonesia di bawah Vietnam. Data yang lain dilaporkan oleh; The World Economic Forum Swedia (2002), bahwa Indonesia memiliki daya saing rendah, yaitu menduduki urutan ke 37 dari 57 negara. (http://jurnal. fip.um.ac.id/ sekolahdasar/pengembangan-model-untuk-m...)

Data siswa menurut Trends in Mathematic and Science Study 2003/2004 mencatat bahwa siswa Indonesia (SD) hanya berada di ranking ke-35 dari 44 negara dalam hal prestasi matematika dan di ranking 37 dari 44 negara dalam hal prestasi sains. Dalam skala Internasional menurut Bank Dunia, Study IFA di Asia Timur menunjukkan ketrampilan membaca siswa kelas IV SD Indonesia berada pada tingkat rendah apabila dibandingkan dengan Negara lain yaitu Hongkong 75,5\%, Singapura $74 \%$, Tailand $65,1 \%$, sedangkan Indonesia berada pada posisi 51,7 \%. (Sumardi, 2012).

Berdasarkan data rendahnya kualitas pendidikan di Indonesia tersebut di atas penyebab utamnya adalah kesalahan paradigma pendidikan yang dalam hal ini adalah kurikulum yang kurang sesuai tuntutan jaman, dan sistem pembinaan guru yang hanya berorientasi pada projek. Padahal di Negara maju (Jepang), model pembinaan guru yang berorientasi pada projek tidak dikenal, model pembinaan guru yang dipilih di Jepang berbasis lesson study, model ini selah dikembangkan di Jepang sejak tahun 1914 (100 tahun yang lalu) dan berhasil, mendapatkan pengakuan dunia.

Analisis situasi terhadap Sekolahsekolah Muhammadiyah Kartasura sebagai mitra pengabdian kepada masyarakat dengan Prodi Pendidikan Geografi FKIP Universitas Muhammadiyah Surakarta bahwa sekolah mitra tersebut menghadapi berbagai masalah. Mengacu pada analisis situasi maka prioritas permasalahan yang dihadapi oleh 26 guru SDIT Muhammadiyah Gompang, 11 guru MIM Kertonatan, 11 guru MIM Pucangan, 23 guru MIM PK Kartasura, 19 guru MIM Gonilan, 31 guru SMP Muhammadiyah, 8 guru SMP Muhammdiyah 2, 15 guru SMA Muhammadiyah, dan SMK Muhammadiyah (282 guru-guru Muhammadiyah Kartasura) sebagaian besar belum pernah mendapatkan pelatihan implementasi kurikulum 2013.

Selain itu sejumlah Sekolah Muhammadiyah Kartasura tersebut juga belum melaksanakan kurikulum 2013, padahal pada tahun ini (Tahun Ajaran baru 2014/2015) Pemerintah telah menganjurkan (mewajibkan) semua sekolah dari SD s/d SLA harus sudah melaksanakan kurikulum 2013, karena itu untuk menyambut anjuran Pemerintah tersebut dipandang sangat perlu diberikan pembekalan dalam bentuk workshop dan pelatihan implementasi kurikulum 2013 kepada guru-guru tersebut.

Tim pengabdian masyarakat prodi pendidikan geografi FKIP-UMS terpanggil mengambil bagian dan bekerja sama dengan Majlis Dikdasmen Muhammadiyah Cabang Kartasura untuk mengadakan kegiatan 
workshop dan pelatihan implementasi kurikulum 2013 berbasis lesson study.

Permasalahan yang muncul adalah; 1) Bagaimana strategi implementasi pembelajaran IPS (Ilmu Pengetahuan Sosial) Kurikulum 2013 berbasis lesson study di Sekolah Muhammadiyah Kartasura. 2) Bagaimana rasionalisasi dan elemen perubahan Kurikulum 2013. 3) Bagaimana proses pembelajaran dan proses penilaian sesuai tuntutan Kurikulum 2013.

Tijauan Pustaka. Lesson study adalah lesson study yang dikembangkan di Jepang, bahwa; Lesson study originated from Japan (of words: jugyokenkyu). Jugyou (intruction, lesson), kenkyuu (research, study), is a systematic process used by Japanese teachers to test the effectiveness of teaching in order to improve learning outcomes, lesson study was developed in the 1870s (Inagaki and Sato, 2012: 3). It is a model case analysis of learning activities that aim to help develop the professionalism of teachers and giving them the opportunity to learn from each other on the basis of real activity in the classroom. In Japan, lesson study as a model of teacher training is very effective, and can increase the professionalism of teachers and quality of

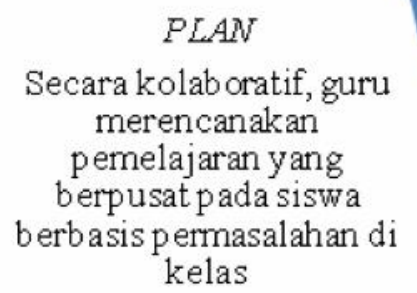
(Subadi, 2013: 104). gambar di bawah ini:

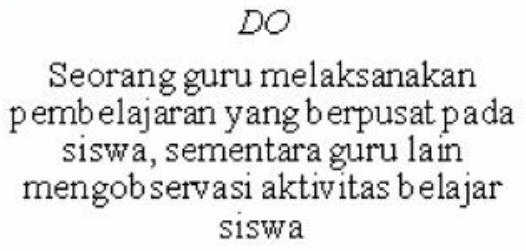

Seorang guru melaksanakan pembelajaran yang berpusat pada siswa, sementara guru lain mengobservasi aktivitas belajar siswa as a development educator in continuity where teachers analyze lesson plans, activities, observations, and reflections collaboratively. This model motivates students to take an active and collaborative learning while teachers try to make students familiar with the 'learning'

Lesson study sebagai salah satu kegiatan pembelajaran bertujuan untuk meningkatkan kompetensi guru dan kualitas pembelajaran. Menurut Paidi, (2005) lesson study diartikan sebagai studi untuk analisis atas suatu praktik pembelajaran yang dilaksanakan dalam bentuk pembelajaran berbasis riset untuk menemukan inovasi pembelajaran tertentu. Dalam banyak literatur pembelajaran berbasis lesson study merupakan pembelajaran yang bersiklus, siklus dalam pembelajaran berbasis lesson study ini dilaksanakan dalam 3 (tiga) tahap, yaitu; "Plan" (merencanakan), "Do" (melaksanakan dan observasi), "See" (merefleksi dan evaluasi), ketiga tahap tersebut dilaksanakan secara kolaborasi dan berkelanjutan (Saito, 2006). Secara sederhana dapat dilihat pada

Gambar: Siklus Pembelajaran Berbasis Lesson Study

(Model Saito, 2006) 
Menurut Lewis (2002) ide yang terkandung di dalam lesson study sebenarnya singkat dan sederhana, yakni jika seorang guru ingin meningkatkan pembelajaran, salah satu caranya adalah guru harus mau berkolaborasi dengan guru lain untuk membuat rencana pembelajaran, melaksanakan pembelajaran dan observasi, melakukan refleksi dan evaluasi terhadap pembelajaran yang dilakukan. Dengan kata lain lesson study merupakan model pembinaan profesi pendidik melalui pengkajian pembelajaran secara kolaboratif dan berkelanjutan, berlandaskan prinsip-prinsip kolegialitas dan saling membantu dalam pembelajaran untuk membangun komunitas belajar, lesson study adalah suatu proses sistematis yang digunakan oleh guru-guru untuk menguji efektifitas pembelajaran untuk meningkatkan hasil pembelajaran, proses sistematis yang dimaksud adalah kerja guru-guru secara kolaboratif dalam mengembangkan rencana pembelajaran (lengkap dengan lampirannya), pelaksanaan pembelajaran dan observasi, melakukan refleksi, evaluasi dan revisi.

Apabila di mencermati konsep dasar lesson study, maka terdapat 7 (tujuh) kata kunci, yaitu; pembinaan profesi, pengkajian pembelajaran, kolaborasi, berkelanjutan, kolegialitas, mutual learning, dan komunitas belajar, tujuannya adalah untuk pembinaan profesi pendidik secara berkelanjutan agar terjadi peningkatan kualitas profesi pendidik secara terus menerus, sebab jika tidak dilakukan pembinaan terhadap guru, maka akan terjadi penurunan kualitas profesionalisme guru.

Penelitian Tjipto Subadi (2008) dengan judul; Peningkatan Kualitas Pembelajaran Mata Kuliah Psikologi Umum dengan Model Lesson Study Pada Program Studi PGSD FKIP-UMS. Penelitian ini berkesimpulan bahwa permasalahan yang dihadapi dosen dalam peningkatan kualitas perkuliahan dengan pendekatan lesson study adalah (a) permasalahan internal dan (b) permasalahan eksternal. (c) Model Pembinaan Dosen dengan pendekatan lesson study efektif untuk permasalahan tersebut dan mampu meningkatkan kualitas perkuliahan. (d) Model Lesson Study yang cocok dengan Model Berbasis PTK Modifikasi dengan 4 tahap yaitu (1) Tahap Kajian Akademik (2) Tahap Perencanaan (3) Tahap Pelaksanaan dan Observasi dan (4) Tahap Refleksi dan Evaluasi.

Kajian lesson study tersebut di atas sejalan dengan penelitian Tjipto Subadi (Dikti DP2M, 2009) yang berjudul; Pengembangan Model Peningkatan Kualitas Guru Melalui Pelatihan Lesson Study bagi Guru SD Se-Eks Karesidenan Surakarta (Tahun I). Penelitian ini berkesimpulan bahwa; permasalahan yang dihadapi guru SD untuk meningkatkan kualitas pembelajaran dengan pendekatan lesson study; permasalahan internal dan ekternal. Tingkat permasalahan Sangat kesulitan 17,28\%. Cukup kesulitan $30,88 \%$. Sedikit kesulitan 33,99\%. Merasa tidak kesulitan $17,85 \%$.

Action research dari hasil penelitian tersebut berupa Workshop dan Pelatihan Lesson Study dengan Judul: Lesson Study sebagai Model Pembinaan Guru Untuk Meningkatkan Profesionalitas (Guru SD SeEks Karesidenan Surakarta).

Penelitian Subadi (Dikti LP2M: 2010) yang berjudul; Pengembangan Model Peningkatan Kualitas Guru Melalui Pelatihan Lesson Study bagi Guru SD Se-Eks Karesidenan Surakarta (Tahun II). Penelitian ini berkesimpulan; 1) Efektivitas lesson study melelui K3S, implementasinya melalui kegiatan KKG. 2) Validasi lesson study sebagai model pembinaan guru bersekala terbatas dilaksanakan secara terprogram melalui 4 tahapa yaitu a) Kajian akademik 2) Perencanaan (plan) melalui KKG tingkat gugus di sekolah masing-masing 3) Dilaksanakan oleh guru model dan diobservasi oleh teman guru sebidang study (Do) 4) Dilakukan evaluasi dan reflesi (See). 
Action research dari hasil penelitian ini adalah berupa pelatihan dengan judul : Lesson Study sebagai Model Pembinaan Pendidik untuk Meningkatkan Kualitas yang disampaikan dihadapan guru-guru SDN 1 dan 2 Gentan Kec. Baki Sukoharjo.

Penelitian Tjipto Subadi (Hibah Pascasarjana Dikti, 2011. Tahun III) yang berjudul; Pengembangan Model Peningkatan Kualitas Guru Melalui Pelatihan Lesson Study bagi Guru SD Se-Eks Karesidenan Surakarta. (Tahun III). Penelitian ini berkesimpulan bahwa; a) Uji coba lesson study disesuaikan dengan permasalah yang dihadapi dan di laksanakan secara bertahapan yaitu; sosialisasi, workshop dan pelatihan, implementasi lesson study, berkelanjutan berbasis sekolah (kelas). b) Lesson study di butuhkan tem work dan Dana APBN/APBD c) Dampak model pembinaan guru melalui pelatihan lesson study terhadap PBM dan kualitas guru SD di Karesidenan Surakarta adalah budaya kerja sama antar guru (kolaborasi) dalam lesson study (Kajian akademik-plan-do-see) dan d) Strategi pembelajaran kooperatif di Sekolah Dasar mampu memupuk sikap guru dalam pembelajaran yang aktif, inovatif, kreatif dan menyenamgkan dan menciptakan kelas menjadi surga bagi anak-anaknya, pada gilirannya meningkatkan kompetensi dan profesionalisme guru.

Action research dari hasil penelitian ini adalah berupa pelatihan dengan judul : Lesson Study Sebagai Model Pembinaan Peningkatan Keprofesionalan Pendidik (disampaikan kepada Guru-Guru SD N Makamhaji 1, 2, Action research 3 Kartosuro). Selain itu juga kegiatan pelatihan, dengan judul; Lesson Study Sebagai Mobel Peningkatan Kualitas Pembelajar an GuruGuru Sekolah Dasar (Di sampaikan dalam acara Workshop dan Implementasi Lesson Study Kepada Guru SD Muh. Program Khusus Kota Barat Surakarta. hasil penelitian dalam bentuk pelatihan dengan judul; Lesson
Study sebagai Model Pembinaan dan Pelatihan Guru Profesional (Disampaikan kepada Guru-Guru SDN 1\& 5 Boyolali). Pelatihan dengan judul; Lesson Study sebagai Model Pembinaan dan Pelatihan Pendidik Profesional (Disampaikan kepada GuruGuru SDN 1, 2, 3 dan 4 Kemiri Karanganyar), dan pelatihan dengan judul Peningkatan Mutu Pendidikan Melalui Lesson Study (Disampai kan kepada guru-guru SDN dan SD Muh. Kauman Klaten).

Penelitian Tjipto Subadi yang berjudul; Model Pembinaan Pendidik Profesional (Suatu Penelitian Dengan Pendekatan Lesson Study Pada Guru-Guru Sekolah Muhammadiyah Kabupaten Sukoharjo) Tahun I berkesimpulan bahwa: 1) Implentasi lesson study berbasis MGMP dan berbasis Sekolah. Dampag dari efektivitas lesson study terdapat perbedaan yang signifikan antara sebelun dan sesudah pelaksanaan lesson study yaitu; $15 \%$ dan $50 \%$ untuk siklus I, $20 \%$ dan $50 \%$ untuk siklus II, 2) terjadi peningkatan cukup signifikan pada kompetensi guru indikatornya perangkat pembelajaran menjadi lebih lengkap, penguasaan IT lebih meningkat, pemilihan metode dan strategi pembelajaran lebih tepat. Karena itu prinsip pembinaan guru dengan pendekatan lesson study adalah prinsip keberlanjutan. 3) Kontribusi lesson study antara lain; peningkatan persiapan pembelajaran; menumbuhkan kerja kolaborasi; pengembangan strategi pembelajaran; kolegialitas; kesiapan belajar siswa; perbaikan proses pembelajaran berdasarkan hasil refleksi; pengembangan media pembelajaran; pengembangan perangkat penilaian.

Action research hasil penelitian (2012) adalan Workshop Peningkatan Keprofesionalan Guru Muhammadiyah Sukoharjo Melalui Lesson Study. Pada tahun 2012 dilakukan pendampingan Implementasi Lesson Study di SMK Muhammadiyah 
Sukoharjo. Pendampingan Implementasi Lesson Study di SMA Muhammadiyah Kartosuro dan Pendampingan Implementasi Lesson Study di SMK dan SMP Muhammadiyah Sukoharjo (Silkus 1). Pendampingan Implementasi Lesson Study di SMK dan SMP Muhammadiyah Sukoharjo (Silkus 2). Pendampingan Implementasi Lesson Study di SMK dan SMP Muhammadiyah Sukoharjo (Silkus 3). (2013) Pendampingan Implementasi Lesson Study di SMK dan SMP Muhammadiyah Sukoharjo (Silkus 4). Pada tahun 2014. Pendampingan Implementasi Kurikulum 2013 di Aceh Besar Tahap I. Pendampingan Implementasi Kurikulum 2013 Kabupaten Rembang Tahap II. Pendampingan Implementasi Kurikulum 2013 Kabupaten Cimahi Tahap III. Pendampingan Implementasi Kurikulum 2013 Kabupaten Lampung Utara Tahap I. Pendalaman NS (Narasumber Nasional) Implementasi Kurikulum 2013 Kemendikbud. Menjadi Narasumber Pelatihan Nsional IN (Instruktur Nasional) Implementasi Kurikulum 2013 Kemendikbud.

Tujuan pengabdian masyarakat, secara umum memfasilitasi guru Sekolah Muhammadiyah Kartsura dalam mengimplementasikan Kurikulum 2013 dalam upaya untuk meningkatkan profesionalisme.

Secara khusus tujuan pengabdian masyarakat ini mengkaji dan memahami; 1) Strategi implementasi pembelajaran IPS (Ilmu Pengetahuan Sosial) Kurikulum 2013 berbasis lesson study di Sekolah Muhammadiyah Kartasura. 2) Rasionalisasi dan elemen perubahan Kurikulum 2013. 3) Proses pembelajaran dan proses penilaian sesuai tuntutan Kurikulum 2013.

Manfaat pengabdian masyarakat ini memberikan sumbangan ilmu tetang: 1) Strategi implementasi pembelajaran IPS (Ilmu Pengetahuan Sosial) Kurikulum 2013 berbasis lesson study di Sekolah
Muhammadiyah Kartasura. 2) Rasionalisasi dan elemen perubahan Kurikulum 2013. 3) Proses pembelajaran dan proses penilaian sesuai tuntutan Kurikulum 2013.

\section{METODE PELAKSANAAN}

Tempat yang digunakan untuk pelaksanaan pengabdian masyarakat adalah di SMK Muhammadiyah Kartasura. Waktu pengabdian masyarakat:

Tahap 1: Kegiatan Workshop tanggal 16-18 Juni 2014 dengan judul: Penakerja Implementasi Pembelajaran IPS Berbasis Kurikulum 2013 Melalui Lesson Study di Sekolah Muhammadiyah Kartasura. Tahap 2: Pendampingan Imlpementasi Pembelajaran IPS Berbasis Kurikulum 2013 Melalui Lesson Study di Sekolah Muhammadiyah Di Kartasura di SMA Muhammadiyah Kartasura. Peserta pengabdian masyarakat adalah guru SD/MI, SMP, SMA dan SMK Muhammadiyah Kartasura sebanyak 282 guru. Tabel Dafta peserta workshop dan pelatihan dapat dilihat pada ( Tabel 1 Lampiran 1).

Pendekatan pengabdian kepada masyarakat yang telah disepakati bersama antara tim pengabdian kepada masyarakat PENAKERJA dengan mitra (Kepala-Kepala Sekolah dan Majlis Dikdasmen Muhammadiyah Kartasura) yaitu; workshop, pelatihan dan pendampingan pembelajaran implementasi kurikulum 2013.

Metode yang digunakan dalam workshop dan pelatihan ini adalah; Pertama, Ceramah, Tanya Jawab, dan Kerja Kelompok. Metode ini digunakan untuk menyampaikan materi antara lain: Rasionalisasi dan Elemen perubahan Kurikulum 2013. Standar Kompetensi Lulusan (SKL), Kompetensi Inti (KI), dan Kompetensi Dasar (KD). Strategi implementasi Kurikulum 2013. Cara membuat Rencana Pelaksanaan Pembelajaran (RPP) berbasis Kurikulum 2013. Proses pembelajaran dan proses penilaian sesuai 
tuntutan Kurikulum 2013; Scenario dan proses pelaksanaan pembelajaran berbasis saintifik. Kemampuan guru mengimplementasi Kurikulum 2013 berbasis lesson study.

Kedua, Pelatihan. Metode pelatihan ini digunakan untuk melatih peserta membuat Rencana Pelaksanaan Pembelajaran (RPP) lengkap dengan lampiran-lampirannya, yaitu: Lampiran 1 Pengembangan Materia dan Lembar Kerja Siswa (LKS). Lampiran 2 Instrumen Penilaian Sikap. Lampiran 3 Instrumen Penilaian Pengetahuan. Lampiran 4 Instrumen Penilaian Ketrampilan).

Ketiga, Pendampingan. Pendampingan ini digunakan untuk melatih guru dalam pembelajaran berbasis lesson study. Model ini dimaksudkan memberikan pelatihan kepada guru bidang studi sejenis untuk melakukan pembelajaran berkolaborasi dengan teman sejawat, melalui tahapan; Kajian akademik. Plan (Perencanaan). Do (Tindakan dan observasi). See (Refleksi dan evaluasi). Secara sederhana model pendampingan pembelajaran berbasis lesson study tersebut dapat disederhanakan sebagaimana gambar: Model Lesson Study Modifikasi (Model Tjipto Subadi 2014). (lihat lampiran 2)

Target dari kegiatan pengabdian PENAKERJA ini adalah: 1) terjalinnya kerjasama antara tim pengabdian kepada masyarakat Program Study Pendidikan Geografi dengan Sekolah mitra; 2) Terbentuknya tim pengembangan kurikulum 2013 pada tiap-tiap jenjang di SekolahSekolah Muhammadiyah Kartasura, 3) Peserta pelatihan (guru) memahami rasional Kurikulum 2013, elemen perubahan Kurikulum 2013 (yang di dalamnya dikaji pula Standar Kompetensi Lulusan (SKL), Kompetensi Inti (KI), dan Kompetensi Dasar (KD). 4) Peserta pelatihan memahami strategi implementasi Kurikulum 2013. 4) Peserta dapat membuat RPP berbasis Kurikulum 2013 dengan benar. 5) Peserta memahami cara melaksanakan pembelajaran dan penilaian sesuai tuntutan Kurikulum 2013. 6) Paserta memahami scenario pelaksanaan pembelajaran sesuai tuntutan Kurikulum 2013 berbasis lesson study. 7) Tim memberikan bekal kemampuan guru sebagai pelatih implementasi Kurikulum 2013 berbasis lesson study.

Luaran dari pengabdian masyarakat PENAKARJA ini; 1) Terbentuknya tim ahli implementasi Kurikulum 2013. 2) Model pembinaan guru berbasis lesson study. 3) Publikasi Jurnal Warta LPPM UMS.

\section{HASIL DAN PEMBAHASAN}

\section{Workshop dan Pelatihan}

Kondisi sebelum pengabdian masyarakat. Upaya untuk melaksanakan kebijakan pemerintah berkaitan dengan pelaksanaan Kurikulum 2013, ada beberapa kendala yang dihadapi oleh guru-guru Sekolah Muhammadiyah Kecamatan Kartasura bahwa dari sejumlah 282 guru yang terdiri dari 26 guru SDIT Muhammadiyah Gompang, 11 guru MIM Kertonatan, 11 guru MIM Pucangan, 23 guru MIM PK Kartasura, 19 guru MIM Gonilan, 31 guru SMP Muhammadiyah, 8 guru SMP Muhammdiyah 2, 15 guru SMA Muhammadiyah, dan SMK Muhammadiyah, sebagaian besar guru tersebut belum pernah mendapatkan pelatihan implementasi kurikulum 2013. Selain itu, sejumlah Sekolah Muhammadiyah Kartasura tersebut juga belum melaksanakan kurikulum 2013, padahal pada tahun ini (Tahun Ajaran baru 2014/2015) Pemerintah telah menganjurkan (mewajibkan) semua sekolah dari SD s/d SLA harus sudah melaksanakan kurikulum 2013. Dalam rangkan menyambut anjuran Pemerintah dan menyiapkan guru yang profesional dipandang sangat perlu diberikan pembekalan dalam bentuk workshop dan pelatihan implementasi kurikulum 2013.

Indikator yang akan dicapai. Indikotor yang dicapai dalam workshop dan pelaithan implementasi Kurikulum 2013 adalah para 
guru memahami dan mengimplemantasikan Kurikulum 2013, yang ditekankan pada: 1) Strategi implementasi pembelajaran IPS (Ilmu Pengetahuan Sosial) Kurikulum 203 berbasis lesson study melalui tiga tahap, yaitu; plan (perencanaan), do (tindakan dan observasi), see (refleksi). 2) Rasionalisasi dan elemen perubahan Kurikulum 2013 menekankan pada; a) Pendekatan berbasis scientific approach untuk mendorong kreativitas siswa; b) Keutuhan antara kompetensi pengetahuan, keterampilan, dan sikap; c) Keutuhan antara kurikuler, kokurikuler dan ektra-kurikuler. 3) Proses pembelajaran Kurikulum 2013 ditekankan pada; (a) Tematik terpadu untuk jenjang Sekolah Dasar, (b) Pendekatan IPA (Ilmu Pengetahuan Alam) dan IPS (Ilmu Pengetahuan Sosial) dari partitif agregatif menjadi melebur terintegrasi (liquid Integratif), (c) Pendidikan Agama dan Budi Pekerti, (d) Objek pembelajaran; fenomena alam, sosial, dan seni budaya. Sedangkan proses penilaian ditekankan pada; penilaian capaian siswa dengan menggunakan deskriptif kualitatif dan numerik kuantitaif.

Selain memahami Rasional dan elemen perubahan Kurikulum 2013, juga memahami; Standar Kompetensi Lulusan (SKL), Kompetensi Inti (KI), dan Kompetensi Dasar (KD). 4) Strategi implementasi Kurikulum 2013. 5) Strategi membuat RPP berbasis Kurikulum 2013 dengan benar. 6) Memahami cara melaksanakan pembelajaran. 7) Penilaian sesuai tuntutan Kurikulum 2013. 8) Memahami scenario pelaksanaan pembelajaran sesuai tuntutan Kurikulum 2013 berbasis lesson study. 9) Memberikan kemampuan kepada guru sebagai pelatih implementasi Kurikulum 2013 berbasis lesson study.

Hasil yang akan dicapai. Hasil yang akan dicapai terhadap pemahaman peserta workshop dan pelatihan terhadap materi yang disajikan oleh nara sumber dapat diketahui dari hasil nilai pretes dan postes, yakni ratarata mencapai $30 \%$ nilai pretes dan $65 \%$ nilai postes, yang berarti diharapkan (dipredeksikan) ada kenaikan $35 \%$.

Proses workshop dan pelatihan implementasi Kurikulum 2013 berbasis lesson study. Dalam proses workshop dan pelatihan ini para peserta berperan aktif, baik pada waktu penyajian materi maupun pada saat berja kelompok, bahkan pada saat diberikan kesempatan waktu untuk bertanya terdapat banyak peserta yang mengajukan pertanyaan seputar Kurikulum 2013, pertanyaan yang diajukan antara lain: 1) Mohon penjelasan terkait dengan Kurikulum menurut UU Nomor 20 Tahun 2013. 2) Mohon penjelasan secra singkat terkait dengan pengembangan Kurikulum 2013 merupakan langkah lanjutan Pengembangan Kurikulum Berbasis Kompetensi yang telah dirintis pada tahun 2004 dan KTSP 2006 yang mencakup tiga kompetensi. 3) Mohon dijelaskan kembali urgensi tantangan internal, tuntutan pendidikan yang mengacu kepada delapan Standar Nasional Pendidikan. 4) Apa yang menjasdi faktor sukses implementasi Kurikulum 2013? 5) Apa harapan terhadap IN sebagai Narasumber terhadap implenetasi Kurikulu 2013? 6) Bagaiaman perbedaan mendasar Kurikulum 2013 dengan Kurikulum sebelumnya? 7) Bagaimana penyempurnaan pola pikir Kurikulum 2013? 8) Mohon penjelasan elemen utama perbaikan Kurikulum 2013. 9) Bagaiamana menjelaskan keseimbangan antara sikap, keterampilan dan pengetahuan untuk membangun karakter siswa? 10) Mohon penjelaskan secara singkat prosen penilaian dan yang terkait dengan penilaian Kurikulum 2013.

Capaian Pengabdian Masyarakat. Capaian dari pengabdian masyarakat ini adalah sebagai berikut: Selelah narasumber menjawab pertanyaan-pertanyaan tersebut dengan jelas, kemudian peserta diberikan 
soal-soal untuk dikerjakan secara individual, hasilnya ada peningkatan yang signifikan sebelum pelatihan dengan sudah pelatihan, yaitu; 30\%:80\% walaupun perlu ada yang dijelaskan ulang. Hasil tersebut menunjuukan bahwa terdapat peningkatan yang signifikan antara sebelum dan sesudah workshop dan pelatihan implementasi Kurikulum 2014 (ada kenaikan 50\% > 35\% dari yang dipredeksikan).

Kendala yang dihadapi. Kendala yang dihadapi dalam pengabdian masyarakat ini adalah penyesuaian jadwal kegiatan sekolah yang selalu mersamaan dengan jadwal jam kuliah. Kendala yang lain, pada saat harus melalukan implementasi Kurikulum 2013 dalam bentuk pelatihan (pendampingan) bembelajaran berbasis lesson study belum ada semangat untuk menjadi guru model (susah untuk mencari guru model), meskipun pada akhirnya ada yang sanggup menjadi guru model.

\section{Pendampingan Pembelajaran Berbasis Lesson Syudy.}

Pengabdian masyarakat ini kemudian dilanjutkan pendampingan pembelajaran IPS berbasis kurikulum 2013 melalui lesson study dengan sistem siklus yaitu: pendampingan pembelajaran berbasis lesson study Jenjang SD/MI, SMP, SMA. Sedangkan untuk jenjang SMK pendampingan implementasi di arahkan pada pembelajaran MIPA. Adapun kegiatan pendampingan dengan 3 tahap, yaitu; plando-see

Tahap Plan (Perencanaan). Pada tahap plan ini guru berkolaborasi membuat RPP dan lampirannya (Lampiran 1 Pengembangan Materi dan LKS/Lembar Kerja Siswa; Lampiran 2 Intrumen Penilaian Sikap; Lampiran 3 Instrumen Penilaian Pengetahuan, dan Lampiran 4 Instrumen Penilaian Ketrampilan).

Tahap Do (Tindakan dan Observasi). Tahap tindakan dan observasi ini guru berkolaborasi melakukan kegiatan pembelajaran berbasis lesson study, sebagai guru model guru kelas IV sedangkan guru yang lain sebagai observer. Adapun langkahlangkah bembelajarannya sbb: 1) Pendahuluan: Guru model memulai pembelajaran dengan melakukan kegiatan: orientasi, memotivasi, apersepsi, menyampaikan tujuan. 2) Inti Pelajaran: Guru menggunakan pendekatan saintifik (Mengamati, Menanya, Menalar, Mencoba, Membentuk Jaringan) dengan model pembalajaran PBL (Problem Based Learning). 3) Penutup: Guru bersama siswa merumuskan simpulan, evaluasi/postes, refleksi, dan Tindak lanjut.

Tahap Refleksi, Evaluasi dan Revisi. Tahap refleksi ini dilaksanakan setelah pembelajaran selesai, guru berkolaborasi melakukan kegiatan diskusi, mengevaluasi pelaksaan bembelajaran yang telah dilaksanakan, hasil diskusi digunakan untuk revisi persiapan maupun palaksanaan pembelajaran berikutnya. Adapun tahapan tersebut bisa dilihat pada foto (lampiran 3).

\section{SIMPULAN DAN SARAN}

\section{Simpulan}

a. Strategi implementasi pembelajaran IPS (Ilmu Pengetahuan Sosial) Kurikulum 203 berbasis lesson study melalui tiga tahap, yaitu; plan (perencanaan), do (tindakan dan observasi), see (refleksi).

b. Rasionalisasi dan elemen perubahan Kurikulum 2013 menekankan pada; 1) Pendekatan berbasis scientific approach untuk mendorong kreativitas siswa; 2) Keutuhan antara kompetensi pengetahuan, keterampilan, dan sikap; 3) Keutuhan antara kurikuler, ko-kurikuler dan ektra-kurikuler.

c. Proses pembelajaran Kurikulum 2013 ditekankan pada; 1) Tematik terpadu untuk jenjang Sekolah Dasar, 2) Pendekatan IPA (Ilmu Pengetahuan 
Alam) dan IPS (Ilmu Pengetahuan Sosial) dari partitif agregatif menjadi melebur terintegrasi (liquid Integratif), 3) Pendidikan Agama dan Budi Pekerti, 4) Objek pembelajaran; fenomena alam, sosial, dan seni budaya. Sedangkan proses penilaian ditekankan pada; penilaian capaian siswa dengan menggunakan deskriptif kualitatif dan numerik kuantitaif.

Strategi implementasi pembelajaran IPS (Ilmu Pengetahuan Sosial) Kurikulum 203 berbasis lesson study menggunakan model lesson study modifikasi, indikator pencapaiannya adanya peningkatan yang sinifikan dari sebelum worhshop dan pelatihan dengan setelah workshop, yaitu; 30\%:80\% (pretes:pos-tes).

\section{Saran}

Workshop dan pelatihan implementasi Kurikulum 2013 sebagai upaya menuju guru yang professional perlu diupayakan terusmenerus dan berkesinambungan. Workshop dan pelatihan implementasi Kurikulum 2013 ini berbasis lesson study diharapkan bisa dijadikan alternatif sebagai model pembinaan guru profesional, karena model ini sangat efektif dan sesuai dengan pendekatan saitifik yang dianjurkan dalam implementasi Kurikulum 2013.

\section{PERSANTUNAN}

Pada kesempatan ini, tim pengabdian kepada masyarakat PENAKERJA menyampaikan banyak terima kasih kepada: (1) Rektor Universitas Muhammadiyah yang telah membiayai kegiatan pengabdian ini (2) Lembaga Pengabdian Kepada Masyarakat (LPPM) Universitas Muhammadiyah Surakarta yang telah memfasilitasi kegiatan pengabdian ini (3) Dekan FKIP Universitas Muhammadiyah Surakarta yang telah memberikan ijin dan Surat Tugas untuk melaksanakan pengabdian ini (4) Kepala Sekolah Mitra (SD/MI, SMP, SMA dan SMK Muhammadiyah Kartasura yang telah bersedia sebagai mitra kegiatan pengabdian ini.

\section{DAFTAR PUSTAKA}

Inagaki, T. \& Sato, M. (2012). Jugyo Kenkyu Nyumon (Introduction to Lesson Study. Tokyo: Iwanami.

Lewis, Catherine C. 2002. Lesson study: A Handbook of Teacher-Led Instructional Change. Philadelphia, PA: Research for Better Schools, Inc.

Paidi. 2005. Implementasi Lesson Study untuk Peningkatan Kompetensi Guru dan Kualitas Pembelajaran yang Diampunya. A Paper presented in the discussion of MAN 1 Teachers on December 10, 2005, Yogyakarta.

Saito. E. 2006. Development of school based in-service teacher training under the Indonesian Mathematics and Science Teacher Education Project. Improving Schools. Vol.9 (1): 47-59

Subadi. T., Sutarni, Ritas P. Kh. (2013). A Lesson Study as a Development Model of Professional Teachers. (Macrothink Institute Journal International of Educatian. ISSN 1948-5476. Vol. 5, No. 22013). United States. info@ macrothink.org. Website: www.macrothink.org. 
Subadi. T., Saring M. (2007). Peningkatan Kualitas Micro Teaching dan PPL (Program Pengalaman Lapangan) Malalui Lesson Study bagi Calon Guru Matematika pada Program Studi Pendidikan Matematika FKIP-UMS. Laporan Penelitian tidak dipublikasikan. Hibah Pengajaran PHK PMIPA Dikti .2004. Pedoman Penyaluran Hibah LS Batch VI Dikti. Jakarta: Dikti DP2M

Subadi. T., Samino. (2009. 2011. 2012). Pengembangan Model Peningkatan Kualitas Guru Melalui Pelatihan Lesson Study Bagi Guru SD Se-Eks Karesidenan Surakarta Tahun I, II, IIIl. Laporan Penelitian tidak dipublikasikan. Hibah Pasca. Pedoman Penyaluran Hibah LS Batch VI Dikti. Jakarta: Dikti DP2M

Subadi. T., Sutarni. Rita P. Kh., (2013). MODEL PEMBINAAN PENDIDIK PROFESIONAL Suatu Penelitian dengan Pendekatan Lesson Study pada Guru-Guru Sekolah Muhammadiyah Kabupaten Sukoharjo Tahun 1. Hibah PUPT Dikti. Pedoman Penyaluran Hibah LS Batch VI Dikti. Jakarta: Dikti DP2M

Subadi. T (2009). Pengembangan Model Untuk Meningkat kan Kualitas Guru Melalui Lesson Study di Sekolah Dasar Kodya Surakarta. Jurnal Sekolah Dasar Kajian Teori dan Praktik Pendidikan, terakreditasi, Tahun 18 No. 2 Edisi November 2009. ISSN: 08548285, 7 halaman. Penerbit : PGSD Universitas Malang. (URI: http://jurnal. fip.um.ac.id/sekolahdasar/pengembangan-model-untuk-m... 


\section{Lampiran - lampiran}

\section{Lampiran 1}

Tabel 1

Daftar Peserta Workshop Dan Pelatihan Implementasi Kurikulum 2013

\begin{tabular}{|c|c|c|c|}
\hline NO & Guru/Kepala Sekolah & Kelas & Jumlah \\
\hline 1 & SDIT Muh. Al Kautsar Gompang & I, II, IV, V & 4 guru \\
\hline 2 & MIM Kertonatan & I, II, IV, V & 4 guru \\
\hline 3 & MIM Pucangan & I, II, IV, V & 4 guru \\
\hline 4 & MIM PK Kartasura & I, II, IV, V & 4 guru \\
\hline \multirow[t]{3}{*}{5} & MIM Gonilan & I, II, IV, V & 4 guru \\
\hline & Kepala Sekolah dan Wakasek & & 10 orang \\
\hline & & & 30 peserta \\
\hline 1 & SMP Muhammadiyah 1 & VII, VIII & 10 Guru \\
\hline \multirow[t]{3}{*}{2} & SMP Muhammadiyah 2 & VII, VIII & 16 guru \\
\hline & Kela Sekolah dan Wakasek & & 6 orang \\
\hline & & & 32 peserta \\
\hline 8 & SMA Muhammadiyah & VII, VIII & 8 guru \\
\hline 9 & SMK Muhammadiyah & $\mathrm{X}, \mathrm{XI}$ & 16 guru \\
\hline \multirow[t]{2}{*}{10} & Kepala Sekolah dan Wakasek & & 6 orang \\
\hline & & & 31 peserta \\
\hline \multirow[t]{2}{*}{11} & Tim UMS & & 7 orang \\
\hline & Jumlah total & & 100 orang \\
\hline
\end{tabular}


Lampiran 2. Lesson Study Modifikasi (Model Tjipto Subadi 2014)

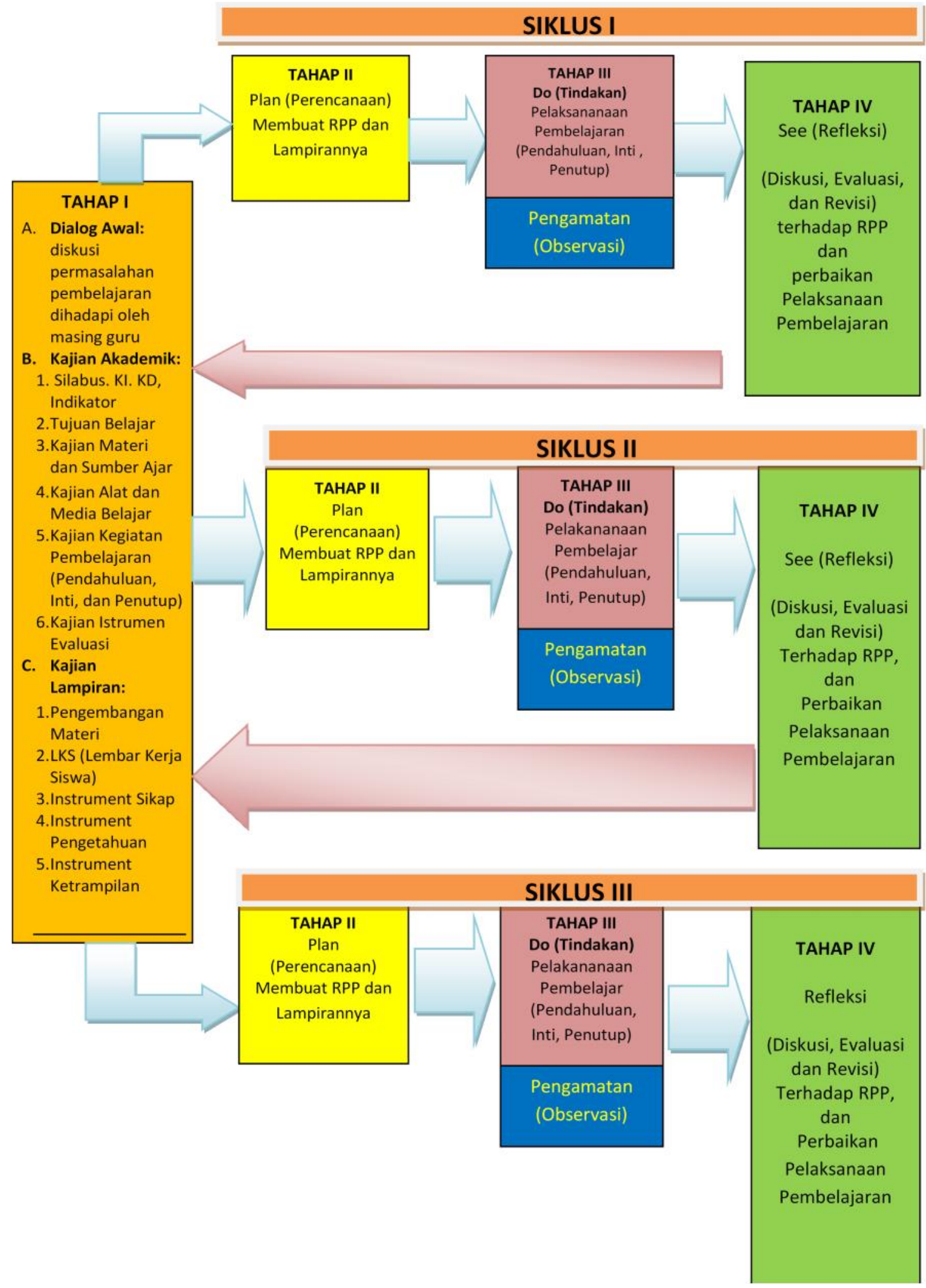

Lesson Study Modifikasi (Model Tjipto Subadi 2014) 
Lampran 3 Foto Tahapan Implementasi Pembelajaran IPS Tepadu Berbasis Lesson Study

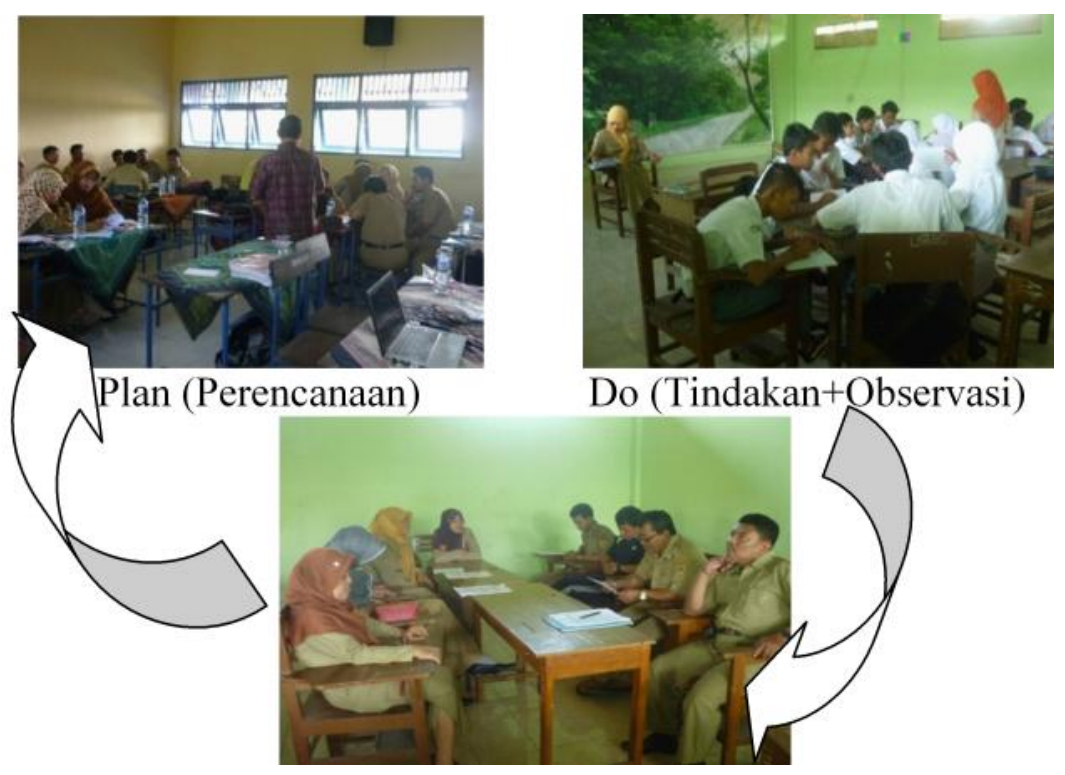

See (Refleksi+Evaluasi) 
